\title{
PEMBERDAYAAN MASYARAKAT MENUJU DESA WISATA DENGAN MEMANFAATAN HASIL ALAM BANJAREJO, TANJUNGSARI, GUNUNG KIDUL
}

\author{
Febritiesna Nuraini dan mahasiswa KKN Reguler devisi V.A \\ Universitas Ahmad Dahlan Yogyakarta \\ E-mail: Febritesna@gmail.com
}

\begin{abstract}
Abstrak
Salah satu permasalahan yang ada di masyarakat Wonosobo 1, 2 dan Melikan, Desa Banjarejo, Kecamatan Tanjungsari, Kabupaten Gunung Kidul, Yogyakarta adalah ketiga dusun tersebut merupakan jalur pariwisata menuju pantai Gunung Kidul. Oleh karena itu, maka program KKN Reguler UAD difokuskan pada pengelolaan mokaf dan pemanfaatan barang bekas. Program ini bertujuan memberdayakan masyarakat ketiga dusun tersebut yang merupakan jalur pariwisata dalam progam pengelolaan mokaf dan pemanfaatan barang bekas guna meningkatkan perekonomian warga. Metode pelaksanaan program KKN meliputi: pendidikan masyarakat, dan praktek langsung. Dampak dari kegiatan KKN ini adalah: 1) tercipta kesadaran masyarakat mengenai potensi sumber daya alam serta pemanfaatan barang bekas yang ada dilingkungan masyarakat, 2) peningkatan pengetahuan masyarakat dalam mengenali potensi sumber daya alam, 3) masyarakat terampil membuat karya kreatif dari barang bekas: bros dari kain perca, keranjang dari koran bekas dan tempat pensil dari kardus.
\end{abstract}

Kata kunci: pemberdayaan, pengelolaan mokaf, pemenfaatan barang bekas

\begin{abstract}
One of the problems in the community of Wonosobo 1, 2 and Melikan, Banjarejo Village, Tanjungsari, Gunung Kidul, Yogyakarta is these sub villages is the tourism lane leading to Gunung Kidul beach. Therefore, the program of Regular Community Service UAD is focused on the management of mocaf and the utilization of used items. The program aims to empower community of these sub villages which is the tourism lane in management of mocaf and utilization of used items program in order to improve the economy of the society. The implementation methods of the program are public education, and practice. The impact of the Community Service activities are: 1) to create public awareness about the potential of natural resources and utilization of used items that exist in the community environment, 2) improving knowledge of the community in recognizing potential natural resources, 3) community skilled at making creative work from used items: brooch from patchwork, a basket from old newspapers and pencil case from cardboard.
\end{abstract}

Keywords: empowerment, management of mocaf, utilization of used items 
Diterbitkan oleh Lembaga Pengabdian kepada Masyarakat

Universitas Ahmad Dahlan Yogyakarta

\section{A. PENDAHULUAN}

Dusun wonosobo I, II, dan Melikan terletak di Desa Banjarejo, Kecamatan Tanjungsari, Gunung Kidul. Dusun-dusun tersebut berada di sebelah selatan Wonosori sekitar $20 \mathrm{KM}$ dekat dengan jalur menuju arah pantai di daerah Gunung kidul yang terkenal dengan keindahannya.

Ketiga dusun tersebut merupakan salah satu jalur alternatif menuju pantai Drini, dimana, akses jalan tersebut cukup mudah dilalui oleh kendaraan darat baik roda dua maupun roda empat. Selain itu, terdapat beberapa potensi sumber daya alam seperti bahan galian $\mathrm{C}$ dan tanaman singkong. Singkong merupakan produksi unggulan yang banyak ditanam oleh masyarakat. Untuk itu, peningkatan mutu singkong dalam hal ini dapat mendukung kesejahteraan pangan dan menyokong ekonomi para petani. Namun dari data dan pengamatan langsung, ketiga dusun dengan daerah potensial jalur pariwisata dan sumber daya alam yang melimpah tersebut masih terbilang sangat kurang. Hal ini ditandakan dengan adanya beberapa permasalahan diantaranya : 1) masih rendahnya kesadaran masyarakat dalam mengelola sumber daya alam yang terdapat di lingkungan tempat tinggal, 2) Kurangnya pengetahuan masyarakat mengenali potensi yang dimiliki, 3) kurangnya ketrampilan masyarakat dalam mengelola sumber daya alam dalam bentuk singkong dan memanfaatkan barang bekas yang terdapat dilingkungan masyarakat dan 4) Kurangnya pengelolaan lingkungan dalam meningkatkan perekomoniaan karena merupakan jalur pariwisata.

Peran serta masyarakat dalam mengelola sumber daya alam yang ada merupakan kesediaan masyarakat untuk membantu berhasilnya program pengelolaan mokaf dan pemenfaatan barang bekas. Tanpa adanya peran serta masyarakat program pengelolaan mokaf dan pemanfaatan barang bekas yang direncanakan akan sia-sia. Salah satu pendekatan masyarakat untuk membantu program pemerintah dalam keberhasilan adalah dapat meningkatkan produktifitas petani singkong dengan pemberdayaan ibu-ibu melalui pengolahan pangan berbahan mocaf dan pemanfaatan barang bekas. Hal ini diharapkan mampu meningkatkan pendapatan masyarakat Gunung Kidul khususnya Desa Wonosobo I, II dan Melikan yang menjadi salah satu jalur menuju pantai.

Berdasarkan permasalahan tersebut, maka ditetapkan tujuan program KKN ini adalah pemberdayaan masyarakat Wonosobo 1, 2 dan Melikan, Banjarejo, Tanjungsari, Gunung Kidul dalam program pengelolaan mokaf dan pemanfaatan barang bekas.

\section{B. METODE PELAKSANAAN}

Untuk mencapai tujuan yang diharapkan, program KKN di dusun Wonosobo I, II, dan Melikan dilaksanakan dengan pemberdayaan masyarakat melalui pendidikan masyarakat, difusi ilmu pengetahuan dan praktek langsung. Ringkasan metode pelaksanaan beserta jam kerja efektif mahasiswa (JKEM) tersaji pada table I berikut. 
Tabel I. Metode, Kegiatan, JKEM dan keterlibatan mahasiswa

\begin{tabular}{|l|l|l|l|l|}
\hline No & \multicolumn{1}{|c|}{ Metode } & \multicolumn{1}{|c|}{ Kegiatan } & \multicolumn{1}{c|}{$\begin{array}{c}\text { Jumlah } \\
\text { mahasiswa } \\
\text { yang terlibat }\end{array}$} \\
\hline 1 & $\begin{array}{l}\text { Pendidikan } \\
\text { masyarakat }\end{array}$ & $\begin{array}{l}\text { Mengadakan } \\
\text { pelatihan inovasi } \\
\text { kuliner }\end{array}$ & 4 x 3 jam & 24 \\
\cline { 3 - 5 } & $\begin{array}{l}\text { Mengadakan } \\
\text { pelatihan } \\
\text { pemanfaatan barang } \\
\text { bekas }\end{array}$ & 4 x 3 jam & 24 \\
\hline 3 & Praktek & $\begin{array}{l}\text { Pelatihan } \\
\text { pembuatan kue } \\
\text { bawang, piscok, } \\
\text { brownies, dan bolu } \\
\text { Pelatihan } \\
\text { pemanfaatan barang } \\
\text { bekas berupa bros, } \\
\text { dan keranjang }\end{array}$ & 4 x 3 jam & 24 \\
\hline
\end{tabular}

\section{HASIL, PEMBAHASAN DAN DAMPAK}

\section{Profil Dusun Wonosobo 1, 2 dan Melikan}

Dusun Wonosobo 1, 2 dan Melikan adalah dusun yang berada di Desa Banjarejo, Kecamatan Tanjungsari, Kabupaten Gunung Kidul, Propinsi Daerah Istimewa Yogyakarta. Ke tiga Dusun mempunyai 307 KK. Dusun ini terletak di dekat Pantai Drini. Jarak dari pusat pemerintahan Desa menuju dusun berjarak 3Km depat di tempuh dengan waktu 1520 menit. Sedangkan jarak pusat dari pemerintahan kecamatan menuju dusun berjarak 7km dapat ditempuh dengan wktu 30-45 menit. Jarak dari pusat pemerintah kabutan menuju dusun berjarak $21 \mathrm{~km}$ dapat di tempuh dengang 1 sampai 1,5 jam. Jarak dari pusat pemerintah propinsi menuju dusun berjarak 60Km dapat ditempuh 1,5 sampai 2 jam.

Batas wilayah yang dimiliki Wonosobo 1 diantaranya, Wonosobo 1 dibatasi dengan RW 01 dan RT 01, 02,03, 04. Sedangkan untuk Wonosobo 2 dibatasi dengan RW 02 dan RT 05, 06, 07, 08. Dan untuk dusun Melikan dibatasi dengan RW 01 dan RT 01,02,03, 04. Batas wilayah sebelah utara, dibatasi oleh dusun Wonosari, untuk batas sebelah selatan dibatasi oleh samudra hindia dan untuk sebelah barat dibatasi oleh dusun Kemadang.

Ketiga dusun tersebut memiliki jumlah komposisi penduduk yaitu sebesar 513 laki-laki dan 539 perempuan dengan rincian: 208 laki-laki dan 225 perempuan di Dusun Wonosobo I, 126 laki-laki dan 136 perempuan di dusun Wonosobo II, dan 179 laki-laki dan 178 perempuan dari Dusun Melikan. Komposisi penduduk berdasarkan jenis kelamin dan persentasinya dapat dilihat gambar 1 . 


\section{Komposisi Penduduk berdasar jenis kelamin}

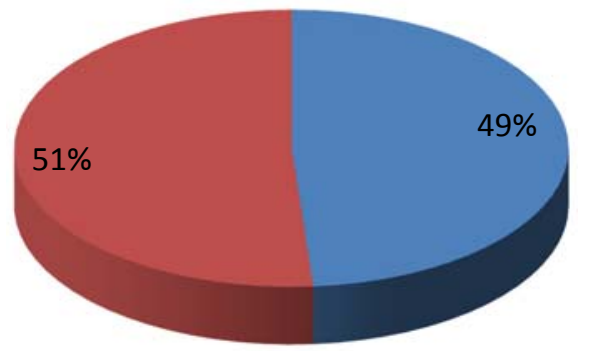

- Laki-laki

Perempuan

Gambar 1. Komposisi penduduk berdasarkan jenis kelamin

Komposisi penduduk berdasar pendidikan formal yaitu usia anak belum/ tidak sekolah sebanyak 260 jiwa, pendidikan SD sederajat sebanyak 409 jiwa, pendidikan SLTP sederajat sebanyak 138 jiwa, pendidikan SMA sederajat sebanyak 41 jiwa, S1 sebanyak 11 orang. Komposisi penduduk berdasarkan pendidikan formal dan persentasinya dapat dilihat dalam gambar 2.

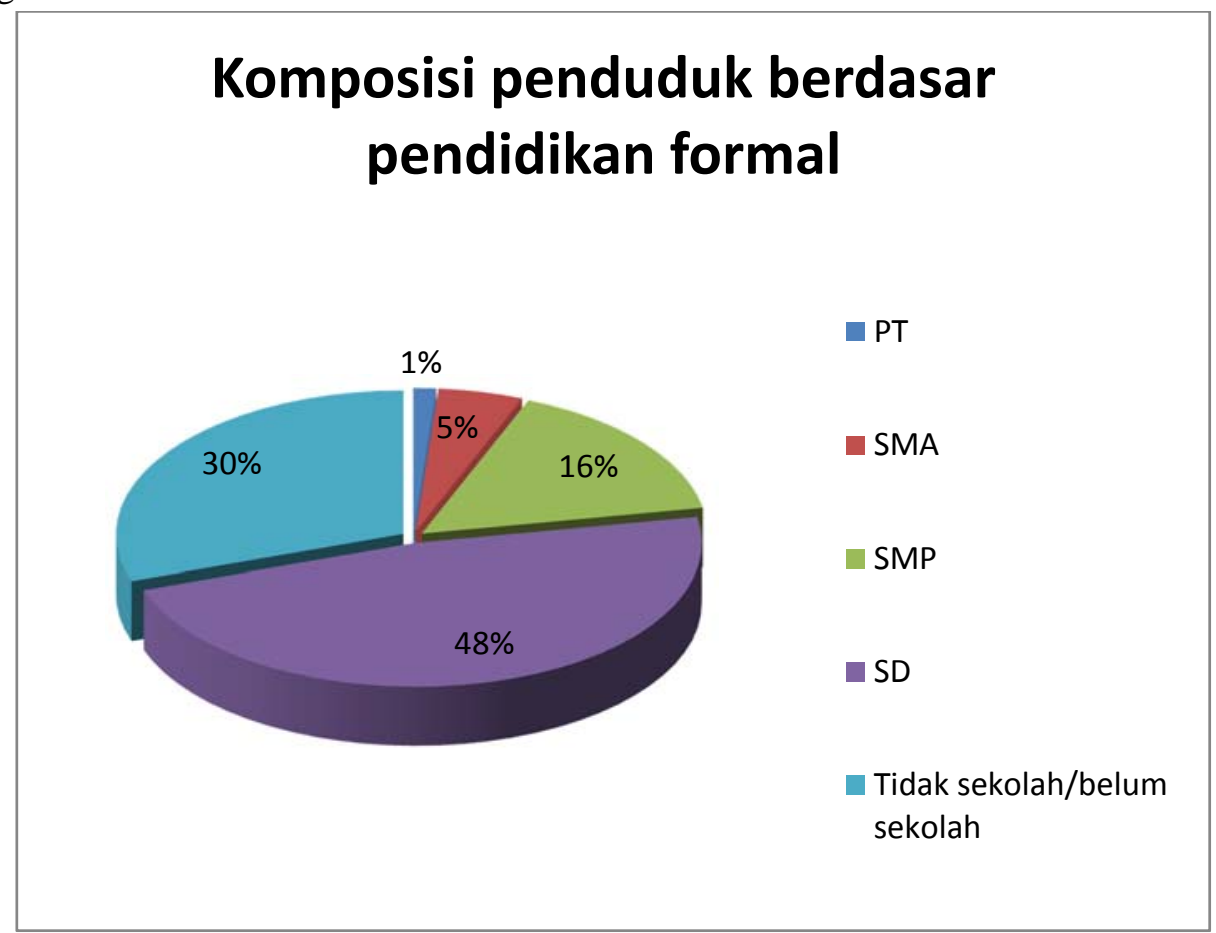

Gambar 2. Komposisi penduduk berdasar pendidikan formal

Komposisi penduduk berdasar mata pencaharian yaitu mata pencaharian sebagai petani sebanyak 141 orang, sebagai Nelayan sebanyak 354 orang, sebagai wiraswasta 
sebanyak 57 orang, sebagai buruh sebanyak 65 orang, sebagai PNS sebanyak 4, sebagai pelajar sebanyak 79 orang, sebagai mahasiswa sebanyak 7 orang. Komposisi penduduk berdasar mata pencaharian tersaji pada gambar 3.

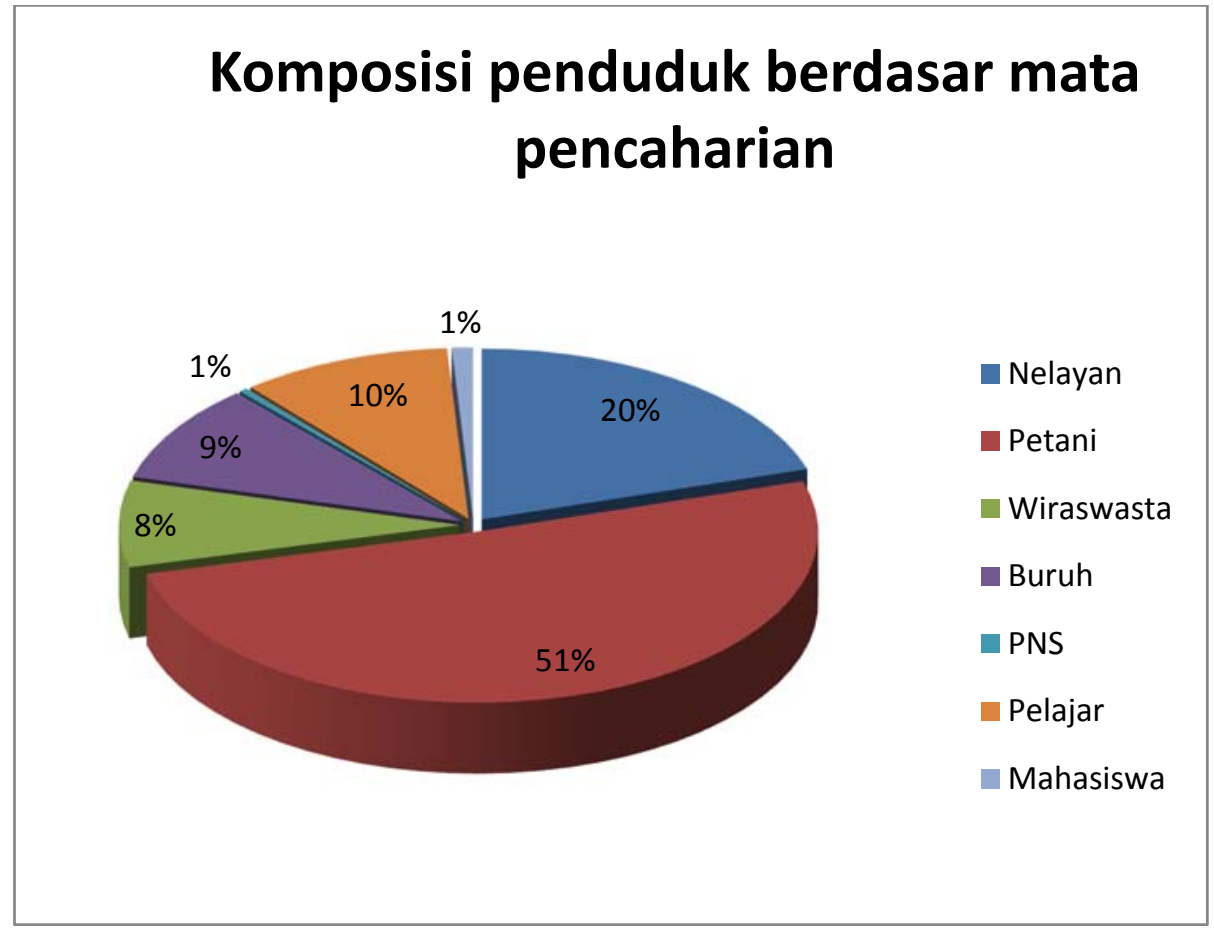

Gambar 3. Komposisi penduduk berdasar mata pencaharian

Cakupan wilayah Kuliah Kerja Nyata Reguler Universitas Ahmad Dahlan Devisi V.A.2 di Dusun Wonosobo 1 meliputi RW 01 yang terdiri dari RT 01, RT 02, RT 03, dan RT 04, sedangkan untuk Dusun Wonosobo 2 meliputi RW 02 yang terdiri dari RT 05, RT 06, RT 07, dan RT 08. Dan untuk Dusun Melikan mencakup seluruh dusun Melikan.

\section{Pembahasan}

Di dusun Wonosobo I, Wonosobo II, dan Melikan mayoritas pekerjaan masyarakatnya adalah sebagai nelayan, petani dan pedagang di pantai Drini. Potensi Sumber Daya Alam yang dimiliki ketiga dusun tersebut sangat banyak. Salah satu diantaranya yaitu perkebunan singkong. Selain itu, daerah tersebut juga merupakan jalur menuju tempat wisata di kawasan pantai Drini. Dengan demikian, maka tugas program KKN Reguler adalah untuk mengenalkan olahan produk singkong kepada masyarakat yang berasal dari perkebunan yang dimiliki warga. Salah satu hasil produk yang dapat di kembangkan dari singkong terseput adalah mokaf. Mokaf merupakan sari pati dari tanaman singkong sehingga dengan mengenalkan mocaf, masyarakat dapat memfaatkan secara maksimal tanaman singkong tersebut.

Berdasarkan hasil wawancara yang dilakukan di tiga dusun tersebut, hampir seluruh masyarakat belum mengenal hasil olahan singkong berupa tepung mokaf. Selain itu, di ketiga dusun tersebut sebelumnya belum pernah mendapatkan pelatihan mengenai 
pengolahan dari tepung mocaf. Hasil olahan dari tepung mokaf diantaranya kue bawang, kue bolu, dan piscok dan brownis kukus yang berbahan dasar tepung mokaf.

Pengenalan hasil olahan tepung mokaf dilakukan dengan cara memberikan pelatihan kepada masyarakat. Dengan adanya kegiatan tersebut, tujuannya adalah untuk meningkatkan ketrampilan dan menumbuhkan kesadaran masyarakat dalam mengenali dan memanfaatkan potensi sumber daya alam yang ada di dusun tersebut. Dengan demikian, dapat meningkatkan perekonomian dan memanfaatkan hasil tanam singkong yang dapat menjadi ciri khas daerah tersebut karena merupakan jalur menuju tempat pariwisata.

Wilayah tersebut merupakan jalur alternatif menuju tempat wisata, banyak masyarakat mengeluh tentang sampah yang berserakan di jalur tersebut. Dengan kondisi tersebut, kami KKN dari dusun Wonosobo I, Wonosobo II dan Melikan memiliki program pelatihan tentang pengelolaan sampah menjadi barang guna. Pelatihan tersebut diantaranya pelatihan pembuatan keranjang, pembuatan bros dan pembuatan celangan. Barang-barang tersebut hasil dari pemanfataan kertas koran bekas, botol bekas dan kain perca. Dengan demikian, maka sampah yang di timbulakan akan dapat bermanfaat dan meningkatkan ketrampilan maupun perekonomian masyarakat.

\section{Dampak}

Dengan adanya pelatihan yang diberikan, maka masyarakat dapat mengenal hasil olahan dari tepung mokaf dimana sebelumnya belum pernah mendapatakan pelatihan tersebut. Selain itu, dapat menumbuhkan ketrampilan dan kesadaran masyarakat mengenai potensi yang ada dilingkungan tempat tinggal. Tentunya, dapat meningkatkan perekonomian masyarakat setempat. Dengan kegiatan ini juga, dapat menambah wawasan dan pengetahuan masyarakat sehingga pemberdayaan masyarakat di ketiga dusun tersebut dapat berjalan dengan maksimal

\section{Gambaran Pelaksanaan}

Gambar aktivitas mahasiswa KKN UAD dari dusun Wonosobo I, II, Melikan dan masyarakat dalam program pengelolaan mokaf dan pemanfaatan barang bekas tersaji pada gambar 4. 


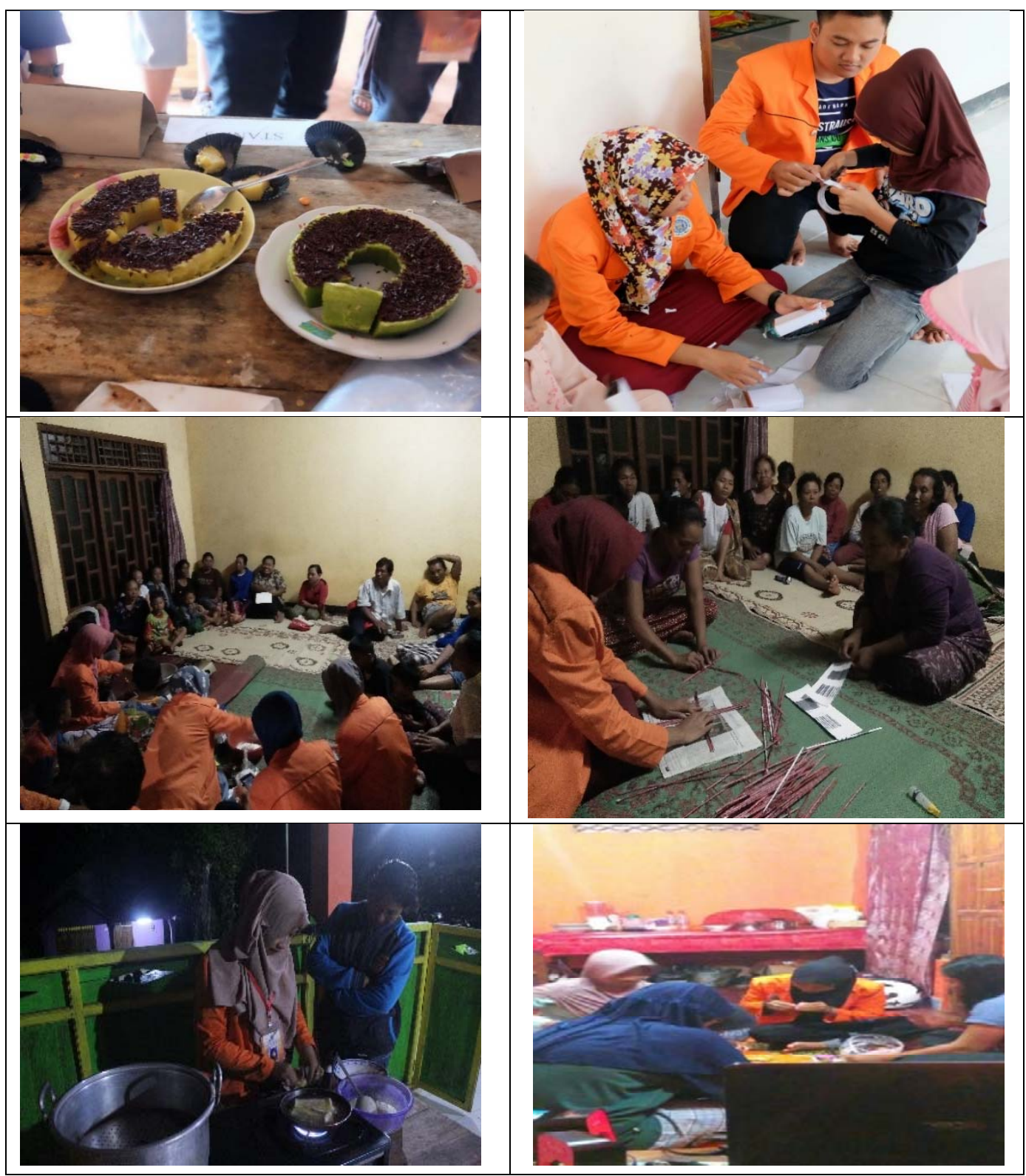

Gambar 4. Aktivitas mahasiswa KKN UAD dan masyarakat dusun Wonosobo I, II, dan Melikan dalam program pengelolaan mokaf dan pemanfaatan barang bekas

Dari gambar 4 terlihat program KKN di dusun Wonosobo I, II, dan Melikan dapat terlaksana dengan partisipasi masyarakat yang cukup tinggi. Dengan kata lain, dapat memperdayakan masyarakat dalam program-program yang telah direncanakan. Dampak dari kegiatan KKN ini adalah: 1) tercipta kesadaran masyarakat mengenai potensi sumber daya alam serta pemanfaatan barang bekas yang ada di lingkungan masyarakat, 2) peningkatan pengetahuan masyarakat dalam mengenali potensi sumber daya alam dan 3) masyarakat terampil membuat karya kreatif dari barang bekas: bros, keranjang dan tempat pensil. 
Diterbitkan oleh Lembaga Pengabdian kepada Masyarakat

Universitas Ahmad Dahlan Yogyakarta

\section{KESIMPULAN}

Program KKN UAD dalam memberdayakan masyarakat di dusun Wonosobo I, II, dan Melikan terhadap pengelolaan mokaf dan pemanfaatan barang bekas telah berjalan dengan baik.

\section{DAFTAR PUSTAKA}

http://uad.ac.id/id/berita/kkn-uad-perdayakan-singkong-bernilai-jual-tinggi

di akses pada tanggal 01 maret 2017

http://m.beritasatu.com/ekonomi388694-gunung-kidul-akan-bentuk-kelembagaan-petanisingkong.html di akses pada tanggal 01 maret 2017 